\title{
Assessment of Ambient Air Quality around Ihetutu Minefield, Ishiagu, Nigeria
}

\author{
A. G. Benibo ${ }^{1 *}$, R. Sha'Ato ${ }^{1}$, R. A. Wuana ${ }^{1}$ and A. U. Itodo ${ }^{1}$ \\ ${ }^{1}$ Department of Chemistry and Centre for Agrochemical Technology \& Environmental Research \\ (CATER), Federal University of Agriculture, Makurdi, Nigeria \\ *Corresponding Author: ao_benibo@yahoo.com; +2348032911770 \\ Received 27 September 2020; accepted 22 October 2020, published online 30 October 2020
}

\begin{abstract}
This study assessed the levels of physicochemical characteristics and heavy metals in ambient air around Ihetutu community in Ishiagu, Nigeria, to evaluate the impact of prolonged $\mathrm{Pb}-\mathrm{Zn}$ mining and several other related activities on air quality in the area. Particulates, heavy metals, microclimatic and gaseous parameters in ambient air were analyzed for the assessment. Sampling and quality measurements were done during rainy, late rainy, dry and late dry seasons between 2018 and 2019, from study and control areas. Samples were analyzed for particulates and heavy metals in the laboratory while microclimatic and gaseous parameters were measured in-situ using standard field equipment and procedures. Mean and seasonal concentrations of parameters were determined to evaluate the ambient air quality at various locations in the study area. Results showed high mean values of some parameters including; ambient temperature $\left(35.19^{\circ} \mathrm{C}\right)$, Relative Humidity $(65.78 \%)$, $\mathrm{SO}_{2}(0.33 \mathrm{ppm}), \mathrm{NO}_{2}(0.30 \mathrm{ppm}), \mathrm{PM}_{10}\left(89.73 \mu \mathrm{g} / \mathrm{m}^{3}\right), \mathrm{Cu}(0.03 \mathrm{mg} / \mathrm{L}), \mathrm{Zn}(0.06 \mathrm{mg} / \mathrm{L}), \mathrm{Fe}(0.39 \mathrm{mg} / \mathrm{L})$, $\mathrm{Mn}(2.28 \mathrm{mg} / \mathrm{L}), \mathrm{Ni}(0.04 \mathrm{mg} / \mathrm{L})$ and $\mathrm{Pb}(0.05 \mathrm{mg} / \mathrm{L})$. Highest Noise level in the study area was 60.40 $\mathrm{dB}(\mathrm{A}) . \mathrm{SO}_{2}$ and $\mathrm{NO}_{2}$ were below detection limits during the dry seasons, but with mean levels above daily average limits of DPR, NESREA, and WHO, due to their high levels during the rainy seasons, except at Amaonye Square. CO mean levels were above FMEnv daily average limit but within DPR limit. $\mathrm{PM}_{10}$ mean values were within NESREA recommended daily average limit while dry season values were above. $\mathrm{Zn}$ and Fe pollution along the stations were in the order of SAS3>SAS4>SAS5, while $\mathrm{Pb}$ pollution was SAS3>SAS4=SAS5. Generally, trend of heavy metal pollution was $\mathrm{Mn}>\mathrm{Fe}>\mathrm{Pb}>\mathrm{Zn}>\mathrm{Cd}=\mathrm{Cu}=\mathrm{Ni}$. Highest positive correlation within the heavy metals was between $\mathrm{Zn}$ and $\mathrm{Fe}(r=1.000)$. There were also no statistically significant differences in means of the parameters among sampling stations $(p>0.05)$. The results revealed pollution of ambient air in the area by heavy metals and gaseous substances, especially around the mining sites and high traffic areas. Proper monitoring of the operations of mining companies and other artisan activities is recommended, to ensure that ambient air status in the area is excellent and within standard guidelines.
\end{abstract}

Keywords: Ambient air, concentrations, particulates, outdoor, workplace.

\subsection{INTRODUCTION}

Atmospheric impacts of mining activities are mainly from generation of dust, and this can be analyzed temporally and spatially in workplace and ambient air qualities around mining communities [1]. Mining activities contribute to the problem of air pollution that adversely affect human health, plants, animals, and valuable objects in and around mining areas either directly or indirectly. The most important emissions or air pollutants during mining are particulate matters, sulfur dioxide, nitrogen dioxide and heavy metals, which deteriorate the air qualities in the mining areas. Activities leading to air pollution in mining areas include drilling, blasting, loading and unloading of overburden, ore, haul roads, transport roads, stock yards, exposed overburden dumps, ore handling plants, exposed pit faces, presence of fire, exhausts from heavy earth moving machinery, crushing of metal ores [2]

Heavy metals such as zinc, cadmium, lead, iron and mercury are common air pollutants emitted mainly from various industrial activities. Although the atmospheric levels are low, they contribute to the deposition and build-up in soils. Heavy metals are persistent in the environment and are subject to bioaccumulation in food-chains [3].

Particulate levels in ambient air are raised by exhaust emissions from mobile sources such as 
cars, trucks, heavy equipment. There are also gas emissions usually from the combustion of fuels in stationary and mobile sources, explosions, and mineral processing. Largescale mining has the potential to contribute significantly to air pollution, especially in the operation phase [4]. According to the National Environmental Standards and Regulations Enforcement Agency (NESREA) [5], in the National Environmental (Air Quality Control) Regulations, no emissions released from the premises of business operational areas or personal facilities into ambient air should exceed $60 \%$ of the prescribed ambient air quality standards, while also considering contributions from other facilities.

The Ihetutu Hill is located in Ishiagu, Ebonyi State of Nigeria, and is within the Lower Benue trough. Lead-zinc and hard rock (aggregate) mining have been ongoing in the area for several decades. The Ishiagu area covers an expanse of land of about $450 \mathrm{~km}^{2}$ and supports an estimated population of over two hundred and fifty thousand people [6,7]. The study area falls within latitudes $5^{\circ} 51^{\prime} \mathrm{N}$ and $5^{\circ} 59^{\prime} \mathrm{N}$ and longitudes $7^{\circ} 24^{\prime} \mathrm{E}$ and $7^{\circ} 40^{\prime}$ $\mathrm{E}$ (Figure 1). The area is accessible through the Enugu-Port Harcourt Railway line, the EnuguPort Harcourt oil pipeline, and the Enugu-Port Harcourt Express Road [8].

Availability of clean air is of utmost importance to all humans, hence the significance of this research to ascertain the quality of air the local dwellers and workers at the various mine sites in Ihetutu are exposed to. The objective of the study therefore is to assess the level of pollution of outdoor air by toxic substances released from the mines and other natural and anthropogenic sources in the study area.

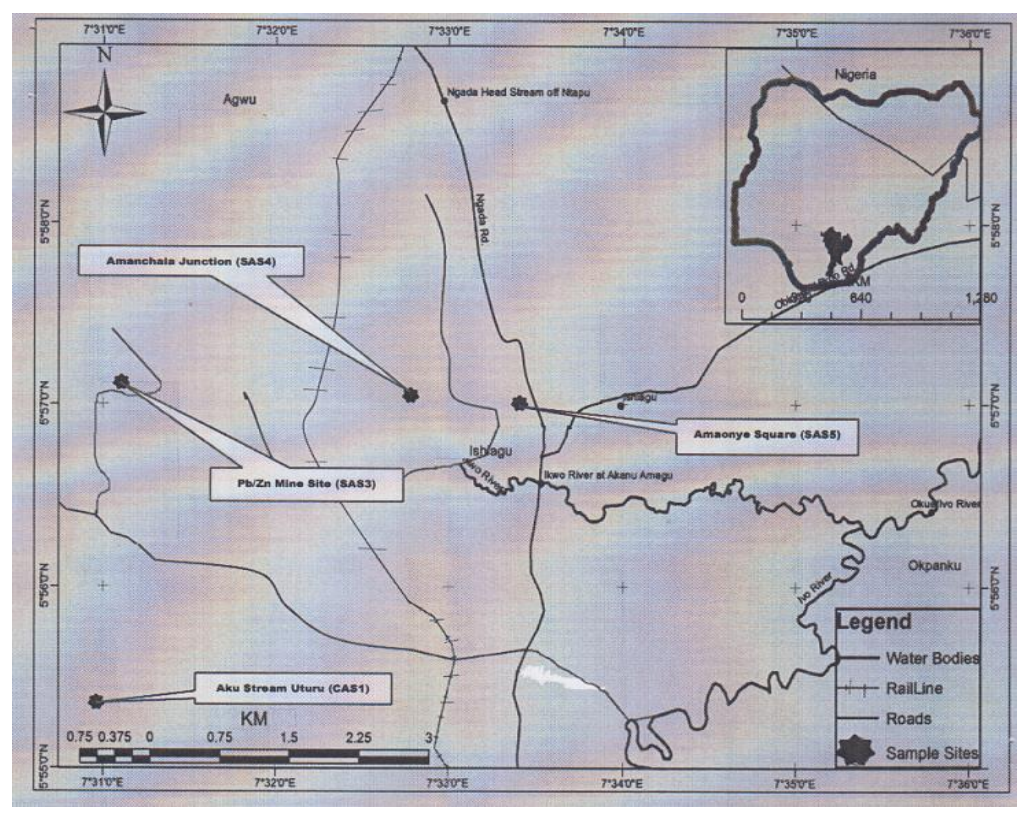

Figure 1: Map Showing Sampling Stations in Study and Control Areas

\subsection{MATERIALS AND METHODS}

\subsection{Sampling and Air Quality Measurement} Ambient air sampling was carried out at four designated sampling stations including control station in the four seasons (Table 1). Station coordinates and wind directions were determined using a GPS meter. A gas analyzer (Madur GA.21 Plus, Aeroqual series 200) was used to determine gaseous parameters directly on site. Ambient temperature, wind speed and relative humidity were determined using an anemometer. Noise levels were measured with the aid of a noise meter. A handheld particulate counter was used to sample for particulate matters. The counter was allowed to run for about $1 \mathrm{hr}$ at a flow rate of $100 \mathrm{~L} / \mathrm{min}$, and then the filter membrane removed, rapped in an aluminum foil, and stored in a polyethylene bag for analysis. The filter membranes were dried in the laboratory for about one hour at $105^{\circ} \mathrm{C}$ and cooled in a dessicator to room temperature. 
Particulate levels $\left(\mathrm{PM}_{10}\right.$ and $\left.\mathrm{PM}_{2.5}\right)$ were determined using Equation 1;

Conc $\left(\mu \mathrm{g} / \mathrm{m}^{3}\right)=\frac{(\mathrm{Ms}-\mathrm{Mo})}{\mathrm{V}} \times 10^{-3}$
Where $\mathrm{M}_{\mathrm{s}}=$ Mass of filter paper after sampling, $\mathbf{M}_{\mathrm{o}}=$ Mass of filter paper before sampling, and $\mathrm{V}=$ Volume of sample $(\mathrm{mL})$.

Table 1: Summary of sampling field data.

\begin{tabular}{|c|c|c|c|c|c|}
\hline $\begin{array}{l}\text { Sampling } \\
\text { Stations }\end{array}$ & Sampling Dates & $\begin{array}{l}\text { Sampling } \\
\text { Seasons }\end{array}$ & $\begin{array}{l}\text { Station } \\
\text { locations }\end{array}$ & Latitude & Longitude \\
\hline $\begin{array}{l}\text { CAS1 } \\
\text { (control) }\end{array}$ & $\begin{array}{l}\text { 11/05/2018; 29/09/2018; } \\
30 / 11 / 2018 ; 12 / 04 / 2019\end{array}$ & $\begin{array}{l}\text { RNS; LRS; } \\
\text { DRS; LDS }\end{array}$ & $\begin{array}{l}\text { Near Aku } \\
\text { Stream, } \\
\text { Uturu }\end{array}$ & N 5 51 '34" & E 7 $31^{\prime} 13^{\prime \prime}$ \\
\hline SAS3 & $\begin{array}{l}\text { 11/05/2018; 29/09/2018; } \\
30 / 11 / 2018 ; 12 / 04 / 2019\end{array}$ & $\begin{array}{l}\text { RNS; LRS; } \\
\text { DRS; LDS }\end{array}$ & $\begin{array}{l}\mathrm{Pb}-\mathrm{Zn} \text { mine } \\
\text { Site, Ihetutu }\end{array}$ & N 5 $51^{\prime} 35^{\prime \prime}$ & E $7^{\circ} 31^{\prime} 13 "$ \\
\hline SAS4 & $\begin{array}{l}\text { 11/05/2018; 29/09/2018; } \\
30 / 11 / 2018 ; 12 / 04 / 2019\end{array}$ & $\begin{array}{l}\text { RNS; LRS; } \\
\text { DRS; LDS }\end{array}$ & $\begin{array}{l}\text { Amanchala } \\
\text { Junction, } \\
\text { Ihetutu. }\end{array}$ & N 5 $55^{\prime} 41^{\prime \prime}$ & E $7^{\circ} 29^{\prime} 5^{\prime \prime}$ \\
\hline SAS5 & $\begin{array}{l}\text { 11/05/2018; 29/09/2018; } \\
30 / 11 / 2018 ; 12 / 04 / 2019\end{array}$ & $\begin{array}{l}\text { RNS; LRS; } \\
\text { DRS; LDS }\end{array}$ & $\begin{array}{l}\text { Amaonye } \\
\text { Square }\end{array}$ & N $5^{\circ} 56{ }^{\prime} 59^{\prime \prime}$ & E $7^{\circ} 33^{\prime} 28^{\prime \prime}$ \\
\hline
\end{tabular}

RNS = Rainy Season; LRS = Late Rainy Season; DRS = Dry Season; LDS = Late Dry Season

2.2 Digestion and Analysis of Heavy Metals

$0.5 \mathrm{~g}$ of grinded and homogenized filter membrane was weighed into a $125 \mathrm{~mL}$ beaker. $100 \mathrm{~mL}$ of distilled water, $0.5 \mathrm{~mL} \mathrm{HNO}_{3}$, and 5 $\mathrm{mL}$ of HCL were added to the beaker in a fume hood. The samples were heated on a hot plate at $90^{\circ} \mathrm{C}$ in the fume hood until the volume was reduced to $20 \mathrm{~mL}$. Mixture was cooled and filtered into a $100 \mathrm{~mL}$ volumetric flask with the aid of glass funnels and filter papers, to remove solids particles from the content. The volume was made up to the $100 \mathrm{~mL}$ mark with distilled water from a wash bottle and then taken for analysis. Standard procedure, ASTM D1971/D4691 [9] was employed for the analysis of heavy metals in the samples, using flame atomic absorption spectrophotometer (FAAS).

\subsection{RESULTS AND DISCUSSION 3.1 Microclimate of the Study Area 3.1.1 Temperature}

The mean ambient air temperature at the sampling stations ranged from 34.49 - 35.19 ${ }^{\circ} \mathrm{C}$, with the maximum recorded at the mine site (SAS3) and the minimum recorded at Amanchala Junction (SAS4) (Table 3). The trend for ambient air temperature showed that SAS3 $>$ SAS5 $>$ SAS4. Mean temperature at the control station near Aku stream (CAS1) was $33.75{ }^{\circ} \mathrm{C}$ and was lower than the values the mean values from the study area. Ambient temperature was highest during the late dry season (LDS) at SAS5 while it was highest during the dry season (DRS) at the mine site, Amanchala Junction (SAS3), and the control site (CAS1) (Table 2). Temperature inversion which limits the vertical circulation of air and results in air stagnation and trapping of gaseous pollutant could lead to the high values of pollutants in dry seasons [10]. Also, according to some literatures, temperature has a positive correlation to the concentration of particulate matters but a negative correlation to relative humidity [11]. 
J. Chem. Soc. Nigeria, Vol. 45, No.6, pp 1203 - 1214 [2020]

Table 2: Seasonal Values of Physico-chemical Parameters and Heavy Metals in Ambient Air

\begin{tabular}{|c|c|c|c|c|c|c|c|c|c|c|c|c|c|c|c|c|}
\hline \multirow[b]{2}{*}{ Parameters } & \multirow[b]{2}{*}{ RNS } & \multicolumn{3}{|c|}{ CAS1 } & \multicolumn{4}{|c|}{ SAS3 } & \multicolumn{5}{|c|}{ SAS4 } & \multicolumn{3}{|c|}{ SAS5 } \\
\hline & & LRS & DRS & LDS & RNS & LRS & DRS & LDS & RNS & LRS & DRS & LDS & RNS & LRS & DRS & LDS \\
\hline Wind speed $(\mathrm{m} / \mathrm{s})$ & 1.80 & 1.60 & 1.20 & 1.30 & 2.20 & 2.00 & 1.60 & 1.20 & 0.80 & 0.50 & 0.30 & 2.00 & 1.00 & 1.20 & 1.80 & 1.50 \\
\hline Noise dB(A) & 50.20 & 52.60 & 60.90 & 54.50 & 51.80 & 55.10 & 69.30 & 65.60 & 54.20 & 50.40 & 59.60 & 58.70 & 57.20 & 56.20 & 60.80 & 59.80 \\
\hline Amb. Temp. $\left({ }^{\circ} \mathrm{C}\right)$ & 35.70 & 30.00 & 35.20 & 34.10 & 34.00 & 35.20 & 36.00 & 35.55 & 35.70 & 30.36 & 36.80 & 35.09 & 34.40 & 33.20 & 34.80 & 36.31 \\
\hline Rel. Hum. (\%) & 59.70 & 60.10 & 63.80 & 62.40 & 60.40 & 60.60 & 66.90 & 75.20 & 60.20 & 62.40 & 71.20 & 62.80 & 64.60 & 62.40 & 52.50 & 60.70 \\
\hline $\mathrm{SO}_{2}(\mathrm{ppm})$ & 0.06 & 0.09 & $<0.1$ & $<0.1$ & 0.09 & 0.12 & $<0.1$ & $<0.1$ & 0.26 & 0.07 & $<0.1$ & $<0.1$ & 0.05 & 0.04 & $<0.1$ & $<0.1$ \\
\hline $\mathrm{NO}_{2}(\mathrm{ppm})$ & 0.04 & 0.07 & $<0.1$ & $<0.1$ & 0.20 & 0.10 & $<0.1$ & $<0.1$ & 0.18 & 0.10 & $<0.1$ & $<0.1$ & 0.01 & 0.03 & $<0.1$ & $<0.1$ \\
\hline $\mathrm{CO}(\mathrm{ppm})$ & 2.60 & 0.17 & $<0.1$ & $<0.1$ & 3.41 & 2.87 & 4.92 & 2.68 & $<0.1$ & $<0.1$ & 3.00 & 0.04 & $<0.1$ & $<0.1$ & 2.00 & 1.89 \\
\hline $\mathrm{PM}_{10}\left(\mu \mathrm{g} / \mathrm{m}^{3}\right)$ & 4.00 & 3.00 & 189.00 & 36.00 & 5.00 & 24.90 & 239.00 & 90.00 & 3.00 & 4.00 & 227.00 & 44.80 & 2.00 & 2.00 & 173.00 & 46.00 \\
\hline $\mathrm{PM}_{2.5}\left(\mu \mathrm{g} / \mathrm{m}^{3}\right)$ & 1.00 & 1.00 & 35.40 & 19.20 & 2.00 & 18.00 & 50.00 & 21.80 & 1.00 & 1.00 & 60.00 & 13.60 & 2.00 & 2.00 & 26.00 & 10.00 \\
\hline $\operatorname{SPM}\left(\mu \mathrm{g} / \mathrm{m}^{3}\right)$ & 26.20 & 27.00 & 46.40 & 35.80 & 36.40 & 46.80 & 68.00 & 38.90 & 60.60 & 35.10 & 59.80 & 20.50 & 57.10 & 37.80 & 50.60 & 31.50 \\
\hline Copper (mg/L) & $<0.01$ & $<0.01$ & $<0.01$ & $<0.01$ & 0.02 & 0.03 & 0.03 & 0.05 & 0.02 & 0.02 & 0.02 & 0.04 & 0.01 & 0.00 & 0.01 & 0.02 \\
\hline Zinc (mg/L) & $<0.005$ & $<0.005$ & $<0.005$ & $<0.005$ & 0.02 & 0.06 & 0.06 & 0.09 & 0.01 & $<0.005$ & 0.03 & 0.04 & $<0.005$ & $<0.005$ & 0.01 & 0.02 \\
\hline Iron $(\mathrm{mg} / \mathrm{L})$ & 0.01 & 0.01 & 0.23 & 0.21 & 0.04 & 0.07 & 0.68 & 0.76 & 0.03 & 0.02 & 0.32 & 0.44 & 0.02 & 0.02 & 0.21 & 0.33 \\
\hline Manganese $(\mathrm{mg} / \mathrm{L})$ & 1.10 & 1.09 & 1.12 & 1.15 & 2.40 & 2.39 & 1.59 & 2.75 & 2.31 & 2.32 & 1.27 & 2.66 & 1.16 & 1.16 & 1.11 & 1.78 \\
\hline Nickel (mg/L) & $<0.001$ & $<0.001$ & $<0.001$ & $<0.001$ & 0.03 & 0.04 & 0.03 & 0.05 & 0.01 & $<0.001$ & 0.02 & 0.03 & $<0.001$ & $<0.001$ & 0.01 & 0.02 \\
\hline Lead (mg/L) & $<0.009$ & $<0.009$ & $<0.009$ & $<0.009$ & 0.04 & 0.04 & 0.06 & 0.08 & 0.02 & 0.04 & 0.03 & 0.05 & $<0.009$ & $<0.009$ & 0.01 & 0.04 \\
\hline Cadmium (mg/L) & $<0.002$ & $<0.002$ & $<0.002$ & $<0.002$ & 0.02 & 0.02 & 0.04 & 0.04 & 0.02 & 0.02 & 0.03 & 0.03 & $<0.002$ & $<0.002$ & 0.01 & 0.02 \\
\hline
\end{tabular}

\subsubsection{Relative humidity}

Relative humidity is the ratio of the amount of water vapour present in the air to the highest possible amount of water vapour at the same temperature. The highest mean value of Relative humidity (RH) was $65.78 \%$ recorded at the mine site (SAS3) while the lowest value was $60.05 \%$ at Amaonye Square (SAS5) (Table 3). The mean value at Amanchala Junction (SAS4) was $64.15 \%$ while that of the control site (CAS) was $61.50 \%$. Relative humidity mean values in study area were in the order of SAS3>SAS4>SAS5 (Table 2). Average ratios of particulates $\left(\mathrm{PM}_{2.5}\right.$ and $\left.\mathrm{PM}_{10}\right)$ increase significantly with relative humidity, and higher relative humidity aggravates particulate matter pollution of air in the winter (dry season) [12]. The high levels of particulates recorded in the study area could also be due to the increased relative humidity. Increase in relative humidity in the atmosphere also reduces amount of solar radiation reaching the earth's surface, as the air absorbs the heat from the solar radiation [13]. This makes the air layer closer to the earth surface to be colder than the upper layers. Pollutant concentration in the air thus increases because of the reduction in the up-going air currents, which also leads to the trapping of pollutants in the air.

\subsubsection{Wind speed}

Average wind speed was $1.75 \mathrm{~m} / \mathrm{s}$ (maximum level) at the mine site (SAS3) and $0.90 \mathrm{~m} / \mathrm{s}$ (minimum level) at Amanchala Junction (SAS4) while at Amaonye Square (SAS5) it was $1.38 \mathrm{~m} / \mathrm{s}$ (Table 3). Average wind speed at control station near Aku stream (CAS1) was $1.48 \mathrm{~m} / \mathrm{s}$. The highest wind speed recorded at the mine site (SAS3) could be due to the topography of the location and absence of surrounding trees, which resulted to the exposure of the entire mine site to intense wind blowing across the area. 


\subsubsection{Noise}

Mean noise levels recorded for the three sampling stations in the study area were 60.45 , 55.73, and 58.50 $\mathrm{dB}(\mathrm{A})$ at SAS3, SAS4 and SAS5 respectively while that of control station (CAS1) was $54.55 \mathrm{~dB}(\mathrm{~A})$ (Table 3). The high noise level at Amaonye (SAS5) and the control station near Aku stream (CAS1) could be due to the closeness of the two stations to major roads where there were high vehicular movements and other human engagements while that at the mine site (SAS3) were due to noise from haulage and other operational trucks, excavation machines/equipment, and several other human activities at the site. Noise levels in both study and control areas were within FMEnv [14] recommended level of 90 $\mathrm{dB}(\mathrm{A})$. Noise levels were higher in the dry seasons. This was due to increased operations at the mine site which also led to increase in sound generation. Also, noise level increased with increase in ambient temperature, as speed of sound increases with increasing temperature [15].

\subsection{Assessment of gaseous substances $\left(\mathrm{SO}_{2}\right.$, $\mathrm{NO}_{2}$ and $\mathrm{CO}$ )}

Seasonal concentrations of $\mathrm{SO}_{2}$ and $\mathrm{NO}_{2}$ in ambient air were below detection limit during the dry seasons, at all stations including the control (Table 2). However, all sites recorded some values for the two gases in both rainy (RNS) and late rainy (LRS) seasons. Mean concentrations of $\mathrm{SO}_{2}$ and $\mathrm{NO}_{2}$ at the mine site (SAS3) and Amanchala Junction (SAS4) (Table 3), were above the daily average limits recommended by NESREA [5], DPR [6], and WHO [15], while at Amaonye Square (SAS5) their concentrations were within recommended limits (Table 4). Mean values of $\mathrm{SO}_{2}$ amongst the stations were in the order; SAS4 $>$ SAS3 $>$ SAS5 while $\mathrm{NO}_{2}$ values were in the order SAS3 $>$ SAS4 $>$ SAS5.

$\mathrm{CO}$ mean concentrations in ambient air at Amanchala junction (SAS4) and Amaonye square (SAS5) were $1.52 \mathrm{ppm}$ and $1.95 \mathrm{ppm}$ respectively, while at SAS3 (mine site) and CAS1 (control station near Aku stream), CO levels were $1.39 \mathrm{ppm}$ and $3.47 \mathrm{ppm}$ respectively (Table 3 ). $\mathrm{CO}$ mean levels at all stations, including control, were above the daily average limit of FMEnv [14], though within the limits of DPR [16] (Table 4). Mean values of $\mathrm{CO}$ amongst the stations were in the order; SAS3>SAS5>SAS4. High CO concentrations could result from incomplete combustion of petroleum products from vehicles and other mechanical sources. Due to its high affinity to haemoglobin in the red blood cells, $\mathrm{CO}$ is extremely poisonous, as it prevents the transportation of oxygen by haemoglobin to essential parts of the body cells [17]. Also, according to reports [18], CO, $\mathrm{NO}_{\mathrm{x}}$ and $\mathrm{SO}_{\mathrm{x}}$ could come from trapped substances and other subsidiary activities taking place within the immediate surroundings of an operational area. The gases are acidic oxides that when dissolved in water will form acids.

\subsection{Assessment of Particulates}

\subsubsection{Suspended particulate matter (SPM)}

The mean concentrations of SPM in ambient air in the study area were $47.53 \mu \mathrm{g} / \mathrm{m}^{3}$, $44.00 \mu \mathrm{g} / \mathrm{m}^{3}$, and $44.25 \mu \mathrm{g} / \mathrm{m}^{3}$ at SAS3, SAS4, and SAS5 respectively. SPM mean values at all three study area stations were in the order SAS3>SAS5>SAS4, and higher than its mean value at the control site near Aku stream (CAS1) (Table 3). Mean SPM values at all sites including the control (CAS1) were within the daily average limits of FMEnv [4], and WHO [15], DPR [16] (Table 4). Suspended particulate matter (SPM) in ambient air results from a wide range of finely divided solids that are dispersed into air from combustion processes, industrial activities or natural sources [19]. It constitutes the sum of all suspended solid and liquid particles in the air, with sizes ranging from about $0.1-30 \mu \mathrm{m}$ in diameter. This complex mixture contains particles such as dust, pollen, soot, smoke, and liquid droplets that could be hazardous [15].

\subsection{2 $\mathrm{PM}_{10}$ and $\mathrm{PM}_{2.5}$}

Mean values of $\mathrm{PM}_{10}$ in the study area were $89.73 \mu \mathrm{g} / \mathrm{m}^{3}, 69.70 \mu \mathrm{g} / \mathrm{m}^{3}$, and $55.75 \mu \mathrm{g} / \mathrm{m}^{3}$ at SAS3, SAS4 and SAS5 respectively. $\mathrm{PM}_{2.5}$ mean concentrations were $14.15 \mu \mathrm{g} / \mathrm{m}^{3}$, $22.95 \mu \mathrm{g} / \mathrm{m}^{3}$, and $18.90 \mu \mathrm{g} / \mathrm{m}^{3}$ at SAS3, SAS4, and SAS5 respectively. Control (CAS1) $\mathrm{PM}_{10}$ and $\mathrm{PM}_{2.5}$ mean values were higher than that of SAS5, in both cases (Table 3). $\mathrm{PM}_{10}$ mean levels were within NESREA [5] daily average limit of $150 \mu \mathrm{g} / \mathrm{m}^{3}$. However, dry season (DRS) concentrations at all three stations in the study area were above the NESREA [5] daily average limit (Tables 2 and 4). Mean values of $\mathrm{PM}_{10}$ in the study area were in the order of 
SAS3>SAS4>SAS5 while $\mathrm{PM}_{2.5}$ values were in the order of SAS3>SAS4>SAS5 (Tables 2).

Generally, particulate matters values obtained from both study and control areas showed significant seasonal variation between rainy and dry seasons, as higher concentrations were recorded in the dry seasons for samples analyzed. The higher values obtained in the dry season (DRS) when maximum values were recorded, could be due to much dust generation and dispersion in the air and less rainfall during the dry season. This could also be the reason highest values were recorded at the mine site (SAS3) where much dust were generated due to constant excavation, haulage, crushing, rock blasting, dumping of wastes, and other operational activities, especially in the dry seasons.

Also, particulate matters concentrations decreased with increasing distance from the mining locations, and increase in relative humidity. This was corroborated by the reports of some earlier researchers $[12,18,20]$.
The higher concentrations of particulate pollutants recorded during the dry seasons could also result from the longer residence time of particulates in the atmosphere in the dry seasons because of low winds and low mixing height [21]. Particulate matters in ambient air are responsible for harmful effects on human health, even in the absence of other air pollutants [15]. They may also cause damage by the discoloration and destruction of painted surfaces, corrosion of metals and building surfaces, soil textiles and clothing; and could as well lead to climate change [11].

Table 3: Mean Values of Physico-chemical parameters in Ambient Air

\begin{tabular}{lcccc}
\hline Parameter & SAS3 & SAS4 & SAS5 & $\begin{array}{c}\text { CAS1 } \\
\text { (Control) }\end{array}$ \\
\hline Wind speed $(\mathrm{m} / \mathrm{s})$ & 1.48 & 1.75 & 0.90 & 1.38 \\
Noise dB(A) & 54.55 & 60.40 & 55.73 & 58.50 \\
Amb. Temp. $\left({ }^{\circ} \mathrm{C}\right)$ & 33.75 & 35.19 & 34.49 & 34.68 \\
Rel. Hum. $(\%)$ & 61.50 & 65.78 & 64.15 & 60.05 \\
$\mathrm{SO}_{2}(\mathrm{ppm})$ & 0.08 & 0.21 & 0.33 & 0.09 \\
$\mathrm{NO}_{2}(\mathrm{ppm})$ & 0.06 & 0.30 & 0.28 & 0.04 \\
$\mathrm{CO}_{(\mathrm{ppm})}$ & 1.39 & 3.47 & 1.52 & 1.95 \\
$\mathrm{PM}_{10}\left(\mu \mathrm{g} / \mathrm{m}^{3}\right)$ & 58.00 & 89.73 & 69.70 & 55.75 \\
$\mathrm{PM}_{2.5}\left(\mu \mathrm{g} / \mathrm{m}^{3}\right)$ & 14.15 & 22.99 & 18.90 & 10.00 \\
$\mathrm{SPM}^{3}\left(\mu \mathrm{g} / \mathrm{m}^{3}\right)$ & 33.85 & 47.53 & 44.00 & 44.25 \\
\hline
\end{tabular}


Table 4: Ambient Air Quality Standard Guidelines and Values

\begin{tabular}{lcccc}
\hline Pollutant & $\begin{array}{c}\text { FMEnv (long-term } \\
\text { Limits, 24 hrs })\end{array}$ & DPR & NESREA & WHO \\
\hline $\mathrm{SO}_{2}(\mathrm{ppm})$ & $0.05 \mathrm{mg} / \mathrm{m}^{3}$ & $0.1-0.15^{\mathrm{a}} \mathrm{mg} / \mathrm{m}^{3}$ & $0.12^{\mathrm{a}} \mathrm{mg} / \mathrm{m}^{3}$ & $0.1-0.15^{\mathrm{a}} \mathrm{mg} / \mathrm{m}^{3}$ \\
$\mathrm{NO}_{2}(\mathrm{ppm})$ & $0.085 \mathrm{mg} / \mathrm{m}^{3}$ & $0.15^{\mathrm{a}} \mathrm{mg} / \mathrm{m}^{3}$ & $0.12^{\mathrm{a}} \mathrm{mg} / \mathrm{m}^{3}$ & $0.08-0.11 \mathrm{mg} / \mathrm{m}^{3}$ \\
$\mathrm{CO}(\mathrm{ppm})$ & $1.0 \mathrm{mg} / \mathrm{m}^{3}$ & $10^{\mathrm{a}} \mathrm{mg} / \mathrm{m}^{3}$ & $5^{\mathrm{b}} \mathrm{mg} / \mathrm{m}^{3}$ & $0.001^{\mathrm{b}} \mathrm{mg} / \mathrm{m}^{3}$ \\
$\mathrm{PM}_{10}\left(\mu \mathrm{g} / \mathrm{m}^{3}\right)$ & & & $150^{\mathrm{a}} \mu \mathrm{gg} / \mathrm{m}^{3}$ & \\
$\mathrm{SPM}\left(\mu \mathrm{g} / \mathrm{m}^{3}\right)$ & $0.15 \mathrm{mg} / \mathrm{m}^{3}$ & $60-90^{\mathrm{a}} \mu \mathrm{g} / \mathrm{m}^{3}$ & & $150-230^{\mathrm{a}} \mu \mathrm{g} / \mathrm{m}^{3}$ \\
Lead & $0.005 \mathrm{mg} / \mathrm{m}^{3}$ & $0.0005-0.001^{\mathrm{d}} \mathrm{mg} / \mathrm{m}^{3}$ & $0.0014^{\mathrm{a}} \mathrm{mg} / \mathrm{m}^{3}$ & \\
Nickel & & & $20.0^{\mathrm{c}} \mathrm{mg} / \mathrm{m}^{3}$ & \\
Cadmium & $0.003 \mathrm{mg} / \mathrm{m}^{3}$ & & $5.0^{\mathrm{c}} \mathrm{mg} / \mathrm{m}^{3}$ & \\
Chromium & $0.001 \mathrm{mg} / \mathrm{m}^{3}$ & & & \\
Manganese & $0.01 \mathrm{mg} / \mathrm{m}^{3}$ & & & \\
Mercury & $0.0003 \mathrm{mg} / \mathrm{m}^{3}$ & & & \\
\hline
\end{tabular}

Note: $\mathrm{a}=$ daily average; $\mathrm{b}=8$-hr average; $\mathrm{c}=$ annual average; $\mathrm{d}=1$-hr average mean; NESREA[5]; FMEnv[14]; WHO[15], DPR[16]

\subsubsection{Heavy metals in ambient air \\ Copper}

Mean concentrations of copper in ambient air was at maximum at the mine site (SAS3) with $0.04 \mathrm{mg} / \mathrm{L}$ while the minimum value $(0.01$ $\mathrm{mg} / \mathrm{L})$ was obtained at Amaonye Square (SAS5); and at Amanchala Junction (SAS4), the mean concentration of copper was 0.02 $\mathrm{mg} / \mathrm{L}$. Concentration at control station (CAS1) was below detection limit $(<0.01 \mathrm{ppm})$ (Table 2). Seasonal concentrations were highest in the late dry season (LDS) at all sampling stations in the study area (Figure 2).

\section{Manganese}

Manganese has a maximum mean value of $2.28 \mathrm{mg} / \mathrm{L}$ at the mine site (SAS3) while its minimum mean value of $1.30 \mathrm{mg} / \mathrm{L}$ was recorded at Amaonye Square (SAS5). Mean concentration at Amanchala Junction (SAS4) was $2.14 \mathrm{mg} / \mathrm{L}$ while at the control site (CAS1), it was $1.12 \mathrm{mg} / \mathrm{L}$ (value lower than the mean values of the study area sampling stations). Also, the highest seasonal concentration of manganese in ambient air $(2.75 \mathrm{mg} / \mathrm{L})$ was recorded in the late dry season (LDS) at the mine site (SAS3) (Table 2) (Figure 2). Manganese concentrations at the various sampling stations in both study and control areas were higher than the recommended 24-hour average limit of 0.01 $\mathrm{mg} / \mathrm{m}^{3}$ by FMEnv [14] (Table 4), though lower than OSHA legal limit of $5.0 \mathrm{mg} / \mathrm{m}^{3}$ for manganese in air (averaged over an 8-hour work day) [22]. Also, air contains low levels of manganese, and breathing air so infested with the metal may expose one to it. Manganese is released into the air from mining activities, automobile exhaust, and industries using manufacturing products containing manganese. Workers exposed to high levels of manganese in workplace air including the $\mathrm{Pb}-\mathrm{Zn}$ mine site SAS3), may suffer nervous systems defects, and other health effects with combination of symptoms which when sufficiently severe is referred to as manganism. This comes with some behavioral changes and other nervous systems effects, which include movements that may become slow and clumsy; schizophrenia, dullness, weak muscles, headaches and insomnia. There is also the probability of men in the area suffering serious health effects such as loss of sex drive and sperm damage if they are constantly exposed to manganese for too long [22].

\section{Nickel}

The mean concentration of Nickel in ambient air was also at maximum at the mine site (SAS3) while the minimum value was obtained at Amaonye Square (SAS5), 0.05 and 0.01 $\mathrm{mg} / \mathrm{L}$ respectively. Mean value at Amanchala 
Junction (SAS4) was $0.02 \mathrm{mg} / \mathrm{L}$ while at the control site (CAS1), Ni concentrations were below detection limit $(<0.001 \mathrm{ppm})$ (Table 2$)$, and thus with a zero mean value. Highest seasonal concentration of $\mathrm{Ni}$ in ambient air $(0.05 \mathrm{mg} / \mathrm{L})$ was recorded in late dry season (LDS) at the mine site (SAS3) (Figure 2), where $\mathrm{Ni}$ particulates were also expected to make up the gaseous pollutants found in the dust generated from the various operational activities at the site. However, $\mathrm{Ni}$ concentrations at all sampling stations were within the recommended annual average limit of $20.0 \mathrm{mg} / \mathrm{m}^{3}$ by NESREA [5] (Table 4).

\section{Zinc}

Highest mean concentration of zinc (0.06 $\mathrm{mg} / \mathrm{m}^{3}$ ) was at the mine site (SAS3) while its lowest mean concentration $\left(0.02 \mathrm{mg} / \mathrm{m}^{3}\right)$ was at Amaonye Square (SAS5). Mean concentration at Amanchala Junction (SAS4) was $0.03 \mathrm{mg} / \mathrm{L}$ while at the control station (CAS1) it was zero, as seasonal concentrations were below detection limit (Tables 2). Also, highest seasonal concentrations were recorded during the late dry season (LDS) (Figure 2) when there were increased activities at the $\mathrm{Pb}$ $\mathrm{Zn}$ mines site. These activities led to injection of gaseous pollutants in the ambient air at the workplace through the dust they generated.

\section{Iron}

Maximum mean concentration of iron in ambient air $\left(0.39 \mathrm{mg} / \mathrm{m}^{3}\right)$ was recorded also at the mine site (SAS3), where lots of excavations, rock-blasting, crushing; haulage, transportation; shifting and dumping of wastes especially during the dry seasons were carried out. These activities generated lots of dusts thereby polluting the ambient air in the workplace with several gaseous pollutants in the dust [18]. The minimum mean concentration of iron $\left(0.15 \mathrm{mg} / \mathrm{m}^{3}\right)$ was recorded at Amaonye Square (SAS5) which was about $1.1 \mathrm{~km}$ away from mine sites. Mean concentration at control station (CAS1) was lower compared to values recorded in the study area. Iron concentrations were lower in the rainy seasons (Figure 2). This followed the report [10] that, concentrations of atmospheric pollutants are usually low in the rainy seasons due to the impact of heavy rainfalls scavenging them even as they are emitted from both natural and anthropogenic sources. This could be the reason for the low concentrations of iron recorded during the rainy seasons.

\section{Lead}

Lead concentration in ambient air was also highest at the workplace of the mine site (SAS3), with a mean value of $0.05 \mathrm{mg} / \mathrm{m}^{3}$ while its lowest value was recorded at Amaonye Square (SAS5) as $0.02 \mathrm{mg} / \mathrm{m}^{3}$. Also, mean concentration of lead at Amanchala Junction was $0.03 \mathrm{mg} / \mathrm{L}$ while its mean value at the control station near Aku stream (CAS1) was zero, with seasonal concentration below detection limit (Table 2). Lead concentrations at all sampling stations in the study area were higher in the dry seasons ((Figure 2), and above standard guideline values of NESREA [5], FMEnv [14], and DPR [16] (Table 4). High lead concentrations in ambient air especially at the mine site (SAS3) were expected, considering the huge lead deposits and the various mining activities constantly carried out at the site including; excavation, blasting, crushing and transportation of ores, shifting and dumping of wastes that generate lots of dusts especially during the dry seasons [18].

\section{Cadmium}

Mean concentrations of cadmium in ambient air were $0.03 \mathrm{mg} / \mathrm{L}$ both at the mine site (SAS3) and Amanchala Junction (SAS4); and $0.02 \mathrm{mg} / \mathrm{L}$ at Amaonye Square (SAS5) while at the control station near Aku stream (CAS1), its mean concentration was zero, as its seasonal concentrations were all below detection limit $(<0.002 \mathrm{ppm})$. The highest seasonal concentration of cadmium in ambient air (0.04 $\mathrm{mg} / \mathrm{L}$ ) was recorded in both dry (DRS) and late dry (LDS) seasons at the mine site (SAS3) (Table 2) (Figure 2). Cadmium levels were also higher than the recommended 24-hour average limit of $0.003 \mathrm{mg} / \mathrm{m}^{3}$ by FMEnv [14] but within annual average limit of $5.0 \mathrm{mg} / \mathrm{m}^{3}$ of NESREA [5] (Table 4). High cadmium concentrations especially at Amanchala Junction (SAS4) during dry seasons could also be due to temperature inversion which limits the vertical circulation of air, and thus results in the stagnation of air and trapping of pollutant in the area [10]. 

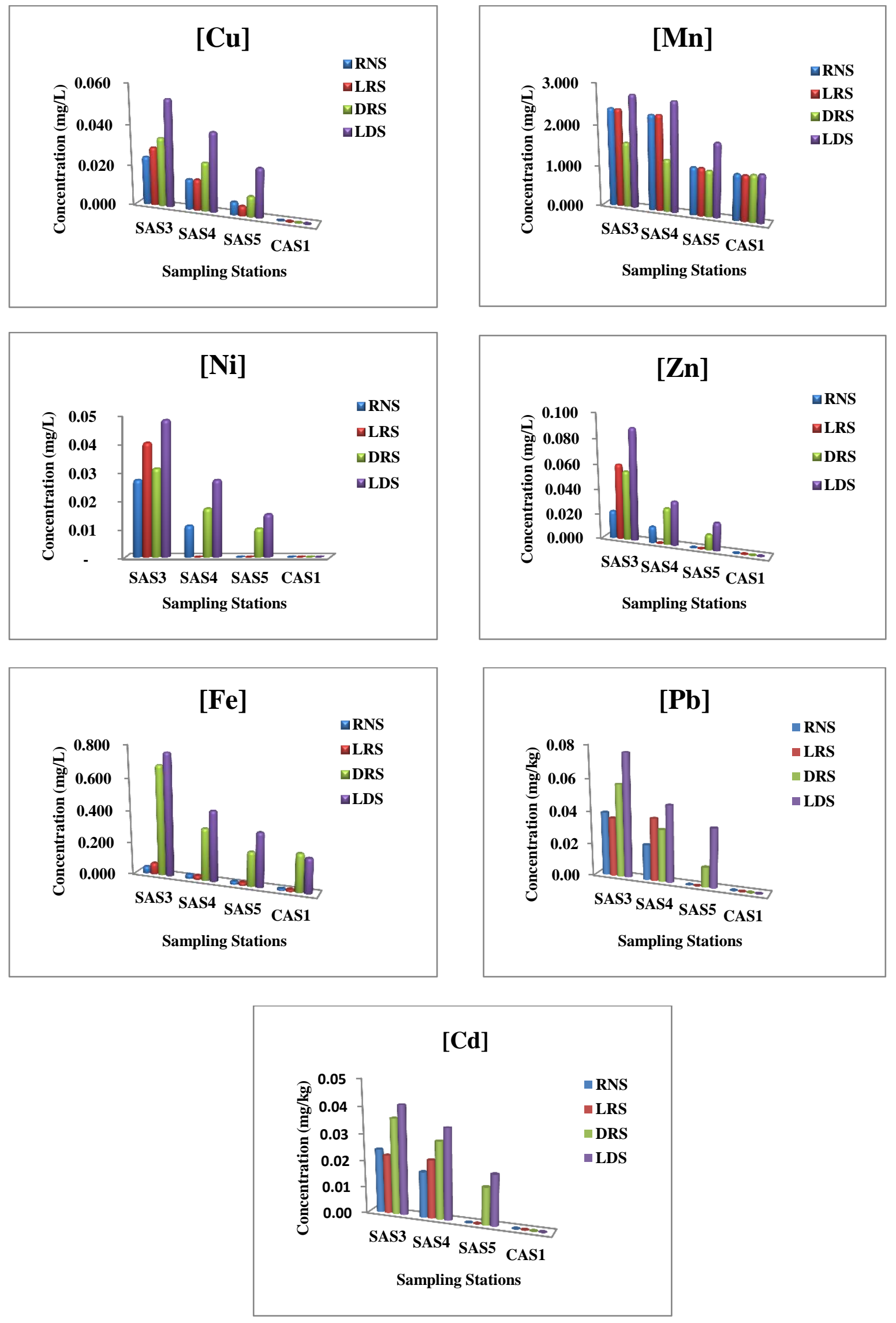

Figure 2: Seasonal Concentrations of Heavy Metals in Ambient Air 


\subsubsection{Correlation}

Correlations among heavy metals in the study area were all strongly positive, with the highest coefficient between $\mathrm{Zn}$ and $\mathrm{Fe}(r=1.000)$, and the lowest between $\mathrm{Ni}$ and $\mathrm{Mn}(r=0.759)$
(Table 5). The positive correlations pointed to similar sources of heavy metal pollution $[23,24]$, which could be the mining operations and other dust generating activities including road construction in the area.

Table 5: Correlations of Heavy Metals in Ambient Air

\begin{tabular}{lrrrrrrr}
\hline & $\mathrm{Cu}$ & $\mathrm{Zn}$ & $\mathrm{Fe}$ & $\mathrm{Mn}$ & $\mathrm{Ni}$ & $\mathrm{Pb}$ & $\mathrm{Cd}$ \\
\hline $\mathrm{Cu}$ & 1 & & & & & & \\
$\mathrm{Zn}$ & 0.948 & 1 & & & & & \\
$\mathrm{Fe}$ & 0.953 & 1.000 & 1 & & & & \\
$\mathrm{Mn}$ & 0.928 & 0.762 & 0.773 & 1 & & & \\
$\mathrm{Ni}$ & 0.947 & 0.999 & 0.998 & 0.759 & 1 & & \\
$\mathrm{~Pb}$ & 0.990 & 0.984 & 0.987 & 0.866 & 0.983 & 1 & 1 \\
$\mathrm{Cd}$ & 0.990 & 0.894 & 0.901 & 0.971 & 0.892 & 0.960 & 1 \\
\hline
\end{tabular}

\subsubsection{Analysis of variance (ANOVA)}

ANOVA was performed at a significance level, $\alpha=0.05$. The results showed no statistically significant differences in means of the parameters among the sampling stations, as $p$-value (0.999) was higher than the significance level.

\subsection{CONCLUSION}

The study has confirmed the deterioration of ambient air quality in and around Ihetutu $\mathrm{Pb}-$ $\mathrm{Zn}$ mining areas of Ishiagu. Levels of physicochemical parameters and heavy metals analyzed were higher than most premining/background values obtained from the control station near Aku stream in Uturu (about $12 \mathrm{~km}$ away from the study area), and referenced standard guidelines. There was an indication of pollution of ambient air, resulting from the regular mining of $\mathrm{Pb}-\mathrm{Zn}$ and other artisan activities in the area, as most parameters were above referenced standard guidelines. Trend of heavy metal pollution, in study area, from the investigation, was $\mathrm{Mn}>\mathrm{Fe}>\mathrm{Pb}>\mathrm{Zn}>\mathrm{Cd}=\mathrm{Cu}=\mathrm{Ni}$, while seasonal variations were mostly in the order of LDS $>$ DRS $>$ LRS $>$ RNS. Also, deterioration of ambient air qualities along sampling stations was in the order of SAS3>SAS4>SAS5. The study also revealed that workplace air at the mining sites was the most deteriorated, considering the high level of toxic substances released to the atmosphere directly from the mining operations. Mining activities in the area have become major sources of high levels of toxic substances released to the atmosphere, with significant adverse health implications on the lives of the people living and working in the area; and other animals, plants and valuable objects in the environment. It is thus, recommended that the government through its regulatory agencies including National Environmental Standards and Regulations Enforcement Agency (NESREA) and the Federal Ministry of Environment, properly monitor and regulate the activities of these mining companies and other related activities. This would ensure that ambient air status in the area is excellent, and not adversely affected by these activities, and is also within standards guidelines. Further study should also be carried out on the health risk of the heavy metal pollution of the workplace/outdoor air on the people in the area. 


\section{References}

[1] M. K. Ghose and S. R. Marjee (2001), Air pollution caused by opencast mining and its abatement measures in India, Journal of Environmental Management, 63(2):193-202.

[2] B. Pandey, M. Agrawal and S. Singh (2014), Assessment of air pollution around coal mining area: Emphasizing on spatial distributions, seasonal variations and heavy metals, using cluster and principal component analysis, Atmospheric Pollution Research, 5:79-86

[3] World Health Organization (WHO) (2007), Health risks of heavy metals from long-range transboundary air pollution, Joint WHO/Convention Task Force on the Health Aspects of Air Pollution, WHO Regional Office for Europe.

[4] Environmental Law Alliance Worldwide (ELAW) (2010), Guidebook for Evaluating Mining Project EIAs, $1^{\text {st }}$ Edition.

[5] National Environmental Standards and Regulations Enforcement Agency (NESREA) (2014), National Environmental (Air Quality Control) Regulations, 2014, Federal Republic of Nigeria Official Gazette, B827-850, 101 (142), Government Notice No. 225.

[6] Imo State Ministry of Works and Transport (IMWT) (1984), Atlas of Imo State Nigeria; C\&G Company, Italy.

[7] I. C. Ezekwe (2009), A Geology of the Okigwe Area of South Eastern Nigeria, Uunpublished PGD Thesis, Department of Geological Sciences, Nnamdi Azikiwe University, Awka (UNIZIK), Nigeria.

[14] Federal Ministry of Environment (FMEnv) (1991), National interim guidelines and standards for environmental pollution control in Nigeria, Federal Environmental Protection Agency (FEPA) Regulations.

[15] Shell Petroleum Development Company of Nigeria Limited (SPDC) (2015),

Environmental Impact Assessment (EIA) of Otumara Associated Gas (AGS) Project in Warri South LGA, Delta State, Final Report
[8] R. Sha'Ato, A. G. Benibo, A. U. Itodo and R. A. Wuana (2020), Evaluation of Bottom Sediment Qualities in Ihetutu Minefield, Ishiagu, Nigeria, Journal of Geoscience and Environment Protection, 8:125-142.

[9] Agency for Toxic Substances and Disease Registry (ATSDR) (2012), Manganese. Public Health Statement CAS \# 7439-96-5, Division of Toxicology and Human Health Sciences. https://www.atsdr.cdc.gov/ToxProfiles/tp151c1-b.pdf

[10] O. N. Maitera, H. Louis, Y. Y. Emmanuel, O. U. Akakuru and E. I. Nosike (2018), Air Quality Index of $\mathrm{CO}$ and $\mathrm{NO}_{2}$ in Ambient Air of Jemita/Yola Metropolis, Adamawa State, Nigeria, Advances in Analytical Chemistry, 8(1):1-5.

[11] O. M. Akinfolarin, C. C. Obunwo and N. Boisa (2018), Air Quality Characteristics of Emerging Industrial Areas in Port Harcourt, Nigeria, Journal of Chemical Society of Nigeria, 43(1):7-14.

[12] F. Liu, Q. Tan, X. Jiang, W. Jiang and D. Song (2018), Effect of Relative Humidity on Particulate Matter Concentration and Visibility during Winter in Chengdu, Huan Jing Ke Xue, 39(4):1466-1472.

[13] J. Ramasamy, B. Kumaravel, S. Palanivelraja and M. P. Chockalingam (2013), Influence of Temperature, Relative Humidity and Seasonal Variability on Ambient Air Quality in a Coastal Urban Area, International Journal of Atmospheric Sciences. http://dx.doi.org/10.1155/2013/264046.

submitted to Federal Ministry of Environment, Abuja.

[16] Department of Petroleum Resources (DPR) (2002), Environmental Guidelines and standards for the petroleum industry in Nigeria (EGASPIN), Issued by The Department of Petroleum Resources, Lagos, 1991, Revised 2002, Pp 279.

[17] A. O. Ajugwo (2013), Negative effects of gas flaring: the Nigerian experience, Journal of 
Environmental Pollution and Human Health, 1(1):6-8.

[18] C. Peter, M. C. Alozie and C. E. Azubuine (2018), Stone Quarrying Impact on Air, Soil, Water in Ebonyi State, Journal of Pollution Effects and Control, 6:225.

[20] V. O. Nwaugo, S. O. Obiekezie and C. A. Etok (2007), Post Operational Effects of Heavy Metal Mining on Soil Quality in Ishiagu, Ebonyi State, International Journal of Biotechnology and Allied Sciences, 2(3):242246.

[21] K. Karar, A. K. Gupta, A. Kumar and A. K. Biswas (2006), Seasonal variations of PM10 and TSP in residential and industrial sites in an urban area of Kolkata, India," Environmental Monitoring and Assessment, 118(1-3):369-381.

[24] S. Dragovi, N. Mihailovi and B. Gaji (2008), Heavy Metals in Soils: Distribution, Relationship with Soil Characteristics and
[19] A. O. Akpan (2016), Environmental Sustainability: Assessing the Impact of Air Pollutants Due to Gas Flaring - Qua Iboe Estuary Case, World Journal of Environmental Engineering,4(1):1-5.

[22] American Society of Testing and Materials (ASTM D1971/4691) (2016), Standard Prac-tices for Digestion of Water Samples for Determination of Metals by Flame Atomic Absorption, Graphite Furnace Atomic Absorption, Plasma Emission Spectroscopy, or Plasma Mass Spectrometry, West Conshohocken, PA: ASTM International.

[23] A. K. Inengite, N. C. Oforka and L. C. Osuji (2010), Survey of heavy metals in sediments of Kolo creek in the Niger Delta, Nigeria, African Journal of Environmental Science and Technology, 4(9):558-566. http://www.academicjournals.org/AJEST.

Radionuclides and Multivariate Assessment of Contamination Sources. Chemosphere, 72:491495. 